\title{
Świat przedstawiony w emitowanych w Polsce audycjach dla dzieci i młodzieży
}

\begin{abstract}
The article is devoted to the content analysis of 19 broadcasts for children and teens in six leading television channels dedicated to minors recipients in Poland. The study has been conducted on the basis of 16 criteria reflecting the positive and negative attributes of the programmes. It has aimed to answer the question of how the world is depicted in these broadcasts, and furthermore what socio-cultural patterns are transmitted to children and adolescents watching their favourite fairy tales and film heroes. The research conducted has proved that it is possible to identify both the best, most valuable from the point of view of the child's development and socialization channel (it is MiniMini+) and the most harmful, presenting negative values and negative patterns channel (which is Cartoon Network). The text presents the first in Polish media and sociological studies comparative analysis of such a large number of broadcasts for children and youth, and the analysis so widely verifying the content and formal elements of these broadcasts.
\end{abstract}

1 Tomasz Gackowski, Wydział Dziennikarstwa, Informacji i Bibliologii, Laboratorium Badań Medioznawczych UW, Uniwersytet Warszawski, Polska, t.gackowski@uw.edu.pl.

2 Karolina Brylska, Wydział Dziennikarstwa, Informacji i Bibliologii, Laboratorium Badań Medioznawczych UW, Uniwersytet Warszawski, Polska, karolina.brylska@uw.edu.pl.

3 Marcin Łączyński, Laboratorium Badań Medioznawczych UW, Uniwersytet Warszawski, Polska, laczynski.marcin@gmail.com. 


\section{Keywords:}

animated TV broadcasts, TV series for children, content analysis, education, media

\section{WPROWADZENIE}

Można powiedzieć, że audycje dla dzieci i młodzieży są specyficzną formą komunikatu medialnego. $\mathrm{Z}$ założenia bowiem realizują dwie rywalizujące ze sobą funkcje współczesnej telewizji - informacyjną (tu raczej: edukacyjną) i rozrywkową, traktując obie te funkcje w sposób równorzędny. Dla odbiorców są więc atrakcyjnym produktem, zajmującym uwagę i wzbogacającym wiedzę o świecie, dla nadawców natomiast źródłem rosnącego dochodu - świadczy o tym choćby fakt powstania i powodzenia kanałów telewizyjnych przeznaczonych dla odbiorców małoletnich. Audycjom tego typu stawia się szczególne wymogi dotyczące formy: powinny być w pozytywnym sensie kształcące, propagujące wartościowe wzorce, etyczne, ale także zrozumiałe i estetyczne ${ }^{4}$. Jak się jednak okazuje, nie-

4 Przyjmując tu kategorie „wartościowego” i „szkodliwego” przekazu autorzy odwołują się do licznych ustaleń badaczy z dziedziny psychologii rozwojowej, którzy analizują i opisują związek pomiędzy treścią i jakością percypowanych treści medialnych a rozwojem dzieci i młodzieży (w sensie fizycznym, psychologicznym i kognitywnym). Wśród wielu tego typu publikacji (instytucji naukowych, rządowych oraz społecznych) można wymienić m.in. następujące: Zimmerman, F., Christakis, D. (2005). Children's television viewing and cognitive outcomes: a longitudinal analysis of national data. Archives of Pediatrics \& Adolescent Medicine, 159 (7), s. 619-625; American Academy of Pediatrics, Committee on Public Education (2001). Media violence. Pediatrics, 108 (5), s. 1222-1226; Jago, R., Baranowski, T., Baranowski, J., Thompson, D., Greaves K. (2005). BMI from 3-6 y of age is predicted by TV viewing and physical activity, not diet. International Journal of Obesity (London). 6, s. 557-564; Viner, R., Cole, T. (2005). Television viewing in early childhood predicts adult body mass index. Journal of Pediatrics, 147 (4), s. 429-435; Johnson, J.G., Cohen, P., Kasen, S., First, M.B., Brook, J.S. (2004). Association between television viewing and sleep problems during adolescence and early adulthood. Archives of Pediatrics \& Adolescent Medicine, 158 (6), s. 562-568; Hancox, R., Milne, B., Poulton, R. (2005). Association of television viewing during childhood with poor educational achievement. Archives of Pediatrics \& Adolescent Medicine, 159 (7), s. 614-618. Jako przykłady badań warto przywołać: Rideout, V.J., Foehr, U.G., Roberts D.F. (2010). Generation M2: media in the lives of 8-18 year-olds. Kaiser Family Foundation; McDonough. P. (2009). TV viewing among kids at an eight-year high. Nielsenwire, dane dostępne na stronie: http://www.nielsen.com/us/ en/insights/news/2009/tv-viewing-among-kids-at-an-eight-year-high.html; Interactive Research Center (2012). Czy telewizja jest dla dzieci? Raport i omówienie wyników dostępne na stronie: http://www. audiowizualni.pl/index.php/aktualnosci/teksty-problemowe/teksty-problemowe-telewizja/5406-czytelewizja-jest-dla-dzieci-raport-z-badan-da-vinci-learning; Kossowski, P. (1999). Dziecko i reklama telewizyjna. Warszawa: Wydawnictwo Akademickie Żak; Jago, R., Baranowski, T., Baranowski, JC., Thompson, D., Greaves, K.A. (2005). BMI from 3-6 y of age is predicted by TV viewing and physical 
zbyt często poddaje się weryfikacji podporządkowanie się tym wymogom przez twórców i dystrybutorów audycji. Niniejszy artykuł poświęcony jest analizie zawartości audycji dla dzieci i młodzieży wyemitowanych w sześciu najpopularniejszych kanałach telewizyjnych przeznaczonych dla odbiorców małoletnich. Zrelacjonowane w tekście badanie zostało zaplanowane w oparciu o kilkanaście kryteriów i miało dać odpowiedź na pytanie, jak wygląda świat przedstawiony w tego typu audycjach, a więc jakie wzorce społeczne i kulturowe przekazywane są dzieciom i nastolatkom śledzącym losy przedstawionych bohaterów. Tego typu przedsięwzięcia badawcze od lat stanowią istotny punkt aktywności regulatorów rynku elektronicznego oraz organizacji trzeciego sektora na całym świecie ${ }^{5}$. Warto zaznaczyć, że niniejszy tekst stanowi pierwszą w polskiej refleksji medioznawczej porównawczą analizę dotyczącą tak dużej liczby audycji dla dzieci i młodzieży i tak szeroko weryfikującą elementy formalne i treściowe rzeczonych audycji.

Zagadnienie to wydaje się również doniosłe społecznie, ponieważ - jak pokazują raporty i doniesienia badawcze ${ }^{6}$ - spędzamy coraz więcej czasu przed telewizorem (także komputerem i urządzeniami mobilnymi), także na rozrywce. Według raportu Kaiser Family Foundation z 2010 r., w ostatnich latach drastycznie wzrosła liczba godzin spędzanych przez dzieci przed odbiornikami - do 7 h 38 min, a jeśli weźmiemy pod uwagę tzw. wielozadaniowość w korzystaniu z mediów przez dzieci (ang. multi-tasking), to zbliżamy się do 11 h (!) spędzanych przez dzieci na oglądaniu/wchodzeniu w interakcję z tzw. mediami rozrywkowymi (ang. entertainment media) - czyli telewizją, Internetem, aplikacjami mobilnymi, grami wideo etc. Aż 70\% ankietowanych dzieci przyznało, że w ich domach nie obowiązują żadne zasady co do czasu korzystania z rzeczonych mediów ${ }^{7}$. Dzieci w szczególno-

activity, not diet, International Journal of Obesity, 29 (6), s. 557-564. Ponadto specyficznie duża jest liczba publikacji tego typu w amerykańskich czasopismach z obszaru pediatrii, m. in. w kwartalniku Amerykańskiego Towarzystwa Pediatrycznego możemy znaleźć ponad 100 publikacji dotyczących samego oddziaływania audycji dla dzieci na ich wzorce zachowania i postawy, por.: http://pediatrics. aappublications.org/search?submit $=$ yes $\& y=0 \&$ fulltext $=$ cartoons $\& x=0$.

5 Por. np. Office of Communications (2007). The future of children's television programming. Pobrane z: http://stakeholders.ofcom.org.uk/binaries/consultations/kidstv/summary/kidstv.pdf; Parents Television Council (2006). Wolves in Sheep's Clothing. A Content Analysis of Children's Television. Pobrane z: https:/www.parentstv.org/PTC/publications/reports/childrensstudy/childrensstudy.pdf; Center for Youth and Media Studies, The Alliance for Children and Television (2007). A National Study on Children's Television Programming in Canada, 2010. Pobrane z: http://www. ymamj.org/pdf/nationalstudy.pdf.

6 Zob. zestawienie danych telemetrycznych AGB Nielsen za 2013 r., pobrane z: http://www. wirtualnemedia.pl/artykul/coraz-dluzej-ogladamy-telewizje-teleexpress-hitem-2013-roku.

7 Por. Kaiser Family Foundation (2010). Generation M2: Media in the Lives of 8 - to 18-Year -Olds. Pobrane z: http://kff.org/other/event/generation-m2-media-in-the-lives-of/. 
ści ${ }^{8}$ są silnie wyeksponowane na różnego typu audycje rozrywkowe (np. analizowane w niniejszym tekście właśnie bajki ${ }^{9}$ oraz sitcomy), które - ze swoim światem przedstawionym, narracyjnie (poprzez media) konstruowanym - stanowią istotny element w poznawaniu i rozumieniu przez małoletnich rzeczywistości społecznej.

\section{AUDYCJE DLA DZIECI - STATUS PRAWNY}

Polscy prawodawca i regulator ustalili zasady emitowania audycji przeznaczonych dla małoletnich. Najważniejsze z tych uregulowań to art. 18 ust. 4-5b Ustawy o radiofonii i telewizji oraz Rozporządzenie KRRiT z dnia 23 czerwca 2005 roku w sprawie kwalifikowania audycji lub innych przekazów mogących mieć negatywny wpływ na prawidłowy fizyczny, psychiczny lub moralny rozwój małoletnich. oraz audycji lub innych przekazów przeznaczonych dla danej kategorii wiekowej małoletnich, stosowania wzorów symboli graficznych i formuł zapowiedzi. Zgodnie z tymi zapisami audycje zawierające sceny lub treści mogące mieć negatywny wpływ na prawidłowy fizyczny, psychiczny lub moralny rozwój małoletnich mogą być rozpowszechniane wyłącznie w godzinach od 23.00 do 6.00. Dodatkowo nadawcy audycji mają obowiązek oznaczania ich przez cały czas emisji odpowiednim symbolem graficznym, informującym o przedziale wiekowym odbiorców, którzy powinni i mogą tę audycję oglądać (lub jej słuchać w przypadku radia). Departament Monitoringu Krajowej Rady Radiofonii i Telewizji systematycznie kontroluje programy telewizyjne i radiowe pod kątem przestrzegania tychże przepisów i piętnuje niewłaściwe praktyki. Jak podaje Departament Polityki Europejskiej i Współpracy z Zagranicą oraz Departament Programowy Biura KRRiT (2011), do

${ }^{8}$ Common Sense Media Research (2012). Children, Teens, and Entertainment Media: The View From The Classroom. Pobrane z: http://www.commonsensemedia.org/sites/default/files/ research/view-from-the-classroom-final-report.pdf, Livingstone, S., Haddon, L. (2009). EU Kids Online: Final report. London: EU Kids online. Pobrane z: http://www.lse.ac.uk/media@lse/research/EUKidsOnline/EU\%20Kids\%20I\%20(2006-9)/EU\%20Kids\%20Online\%20I\%20Reports/ pl_summary.pdf; TNS OBOP, (2004). Lubimy rozmawiać z dziećmi. Pobrane z: http://obop-arch. tnsglobal.pl/uploads/753/TNSOBOP_rodzice_dzieci.doc; TNS OBOP, Gazeta Prawna (2009). Telewizor pilnuje dzieci. Pobrane z: http://tv-cyfrowa.eu/content/tns-obop-telewizor-pilnuje-dzieci; Łachowska, E. (2013). Raport z diagnozy ryzyka uzależnienia od komputera, Internetu i innych mediów cyfrowych. Zespół Szkół Publicznych w Czerniejewie. Pobrane z: http://czerniejewo.org/ pdf/diagnoza_komputer.pdf.

9 Autorzy artykułu rozumieją „bajkę” jako animowaną lub fabularną audycję telewizyjną przeznaczoną dla dzieci lub młodzieży. By uniknąć powtórzeń, w dalszych częściach artykułu termin „bajka” będzie używany wymiennie z terminami „audycja animowana” i „audycja przeznaczona dla dzieci i młodzieży”. 
najczęściej popełnianych przez nadawców telewizyjnych błędów zaliczyć należy:

- zaniżanie kategorii wiekowych;

- mechaniczne znakowanie audycji cyklicznych;

- różne znakowanie tej samej audycji: inne w porze dziennej i inne w nocy;

- nadawanie zapowiedzi audycji przed dozwoloną porą ich emisji;

- różne znakowanie zapowiedzi tej samej audycji.

Brakuje danych, czy i jak stosują się do wymogów prawa nadawcy dysponujący kanałami w całości przeznaczonymi dla nieletnich. Warto natomiast zauważyć, że wylistowane w ustawie i rozporządzeniu kategorie są dość ogólne i trudne do zoperacjonalizowania. Z pewnością istnieje katalog zachowań i zjawisk, które bezspornie można przypisać do wskazanych kategorii, ale niepomiernie większy jest zbiór tych, które mogą rodzić wątpliwości i tworzyć pewną „szarą strefę” w tym zakresie.

\section{PRZEGLĄD LITERATURY - STAN BADAŃ}

Audycje dla dzieci i młodzieży stają się przedmiotem polskiej refleksji badawczej jedynie aspektowo, a jeśli już tak się dzieje, są to analizy z dziedziny psychologii rozwojowej obrazujące wpływ telewizji (pojętej szerzej niż tylko audycje przeznaczone dla dzieci) na proces rozwoju intelektualnego i społecznego dziecka. Badacze z zagranicy podejmują pewne analizy zawartości tego typu programów, ale także raczej z perspektywy psychologicznej niż medioznawczej. Warto także zauważyć, że brakuje raportów przekrojowych, porównawczych, częściej mamy do czynienia ze studiami przypadków lub luźną refleksją teoretyczną, niewspartą pogłębionym badaniem empirycznym.

Przegląd literatury przedmiotu wskazuje, że problem ten był analizowany z różnych perspektyw: socjologicznej, teorii literatury (genealogia i poetyka), rzadziej medioznawczej czy komunikologicznej, najczęściej natomiast - co szczególnie istotne - pedagogicznej. Badano wpływ reklamy (Kossowski, 1998; Litwińska, 2008) oraz w ogóle telewizji (Izdebska, 1995, 2007a, 2007b, red. 2008; red. Juszczyk, Polewczyk 2005, 2007) na rozwój dziecka. Z pewnością istotną gałąź refleksji nad wpływem przekazów medialnych na dzieci i młodzież stanowią publikacje z obszaru edukacji medialnej i pedagogiki mediów - z fundamentalnymi tu pracami autorskimi (2006) i pod redakcją Bronisława Siemienieckiego (2006; 2007, 2008) oraz Janusza Gajdy (1998, 2002), ale także innymi, dotyczącymi animowanej medialności w percepcji dzieci (np. Klus-Stańska, 2004), dziecięcej koncepcji fikcji (Kołodziejczyk, 2003), a także możliwego wpływu portretowa- 
nych w bajkach bohaterów na dzieci i młodzież (Adamczyk, 2007; Wenta, 2007; Sitarczyk, 2005) i prezentowanego w filmach animowanych świata społecznego (Krajewska, 2003). Zajmowano się także atrakcyjnością programów telewizyjnych dla dzieci w oczach samych dzieci (Kirwil, 1999) oraz obrazem dziecka w audycjach i komunikatach medialnych (Łaciak, 2003). Tę listę wzbogacają nieliczne pozycje o wąskiej, ale również wartościowej tematyce, takiej jak np. wpływ treści medialnych na folklor dziecięcy (Marcol, 2005) czy funkcja telewizji w życiu dzieci hospitalizowanych (Sosnowski, 2005).

Publikacje anglojęzyczne (przede wszystkim zawarte w periodykach naukowych) w omawianym obszarze także można podzielić na kilka kategorii tematycznych. W pierwszej znajdują się prace poświęcone percepcji audycji telewizyjnych przez dzieci (np. D’Allesio i in., 2012; Feldman i in, 1996). Kolejna grupa publikacji dotyczy czynnika płci i stereotypów płciowych w bajkach (Ryan, 2010; Baker, Raney, 2007; Cook, Main, 2008) oraz szerszych analiz bohaterów audycji (López-Sánchez i in., 2010). Dość istotną i liczną grupę publikacji stanowią te odnoszące się do związku między konsumpcją mediów (a ściślej: oglądaniem programów przeznaczonych dla dzieci) a nawykami żywieniowymi dzieci i młodzieży (np. Korr, 2008). Kolejna grupa publikacji dotyczy zagadnienia agresji i przemocy, obecnych w omawianych audycjach (Gunter, Harrison, 1997; Coyne, Whitehead, 2008). Kolejną, choć już znacznie mniej liczną, grupę publikacji stanowią te dotyczące zachowań prospołecznych (np. Padilla-Walker et al., 2013). Wreszcie ostatnia, również nieliczna, ale istotna dla relacjonowanego w niniejszym tekście badania kategoria publikacji dotyczy stosunku do osób starszych (Robinson, Anderson, 2006). Można więc powiedzieć, że tematy publikacji zagranicznych potwierdzają pewien uniwersalny katalog istotnych wymiarów czy elementów analizy, takich jak wizerunek dziecka i dorosłych w tych audycjach, zagadnienia agresji i przemocy czy funkcjonowanie płci kulturowej w narracjach bajek.

Podsumowując kwerendę literatury w omawianym obszarze, trzeba zwrócić uwagę na znaczący brak (zwłaszcza w dorobku polskim) publikacji dotyczących audycji dla dzieci i adolescentów, zwłaszcza zaś publikacji relacjonujących przeprowadzone z perspektywy medioznawczej badania empiryczne o charakterze ilościowym. Tę lukę w niewielkim stopniu, ale jednak, próbują niwelować nadawcy i regulatorzy rynku mediów w Polsce (i na świecie także), którzy przeprowadzają badania zawartości audycji dla małoletnich, powodowani obowiązkiem prawnym lub etycznym (np. Parents Television Council, 2006). Polski regulator także prowadził analizy kanałów dla dzieci (choć wycinkowe - por. np. Departament Programowy KRRiT, 2009). 


\section{NOTA METODOLOGICZNA}

Celem badania była rekonstrukcja świata przedstawionego w omawianych audycjach, a więc prezentowanych wzorców bohaterów, zachowań społecznych, wartości. W toku analiz dokonano także opisu schematów narracyjnych, na jakich opierają się audycje, ich języka oraz elementów wskazujących na transmedialność audycji (takie jak np. prezentowanie w trakcie emisji zabawek, gier, gadżetów oraz innych przekazów (np. czasopism) odpowiadających bohaterom bajki).

Badanie zostało przeprowadzone w okresie listopad-grudzień 2013 r. na próbie 19 audycji przeznaczonych dla dzieci i młodzieży, wyemitowanych w sześciu specjalistycznych (kierowanych do odbiorców małoletnich) kanałach telewizyjnych dostępnych w Polsce. Były to odpowiednio: kanał Mini Mini+ (audycje: „My Little Pony”, „Truskawkowe Ciastko”, „Ciekawski George”), TeleToon+ („Supa Strikas”, „Niezwykła piątka na tropie”, „Mój kumpel anioł”), Nickelodeon („Marvin Marvin”, „Spongebob”, „iCarly”, „Pingwiny z Madagaskaru”), Disney Junior („Podróże Justina”, „Art Attack”, „Jej wysokość Zosia”), Disney Channel („Violetta”, „Jessie”, „Blog na cztery łapy”) oraz Cartoon Network („Ben 10 Omniverse”, „Scooby Doo i Brygada Detektywów”, „Plan totalnej porażki”). Analizowano dwa dobrane losowo odcinki każdej audycji. O doborze kanałów i audycji zdecydowało kryterium popularności (za wynikami badań telemetrycznych AGB Nielsen). Badanie przeprowadzono metodą analizy zawartości oraz analizy narracji.

Klucz kodowy składał się z 15 kategorii (podzielonych - prócz pierwszego wymienionego kryterium - na pozytywne i negatywne atrybuty programu): atrakcyjność audycji z perspektywy dorosłych, walory edukacyjne, walory wychowawcze, zachowania prospołeczne, zachowania ekologiczne, szacunek dla starszych, atrakcyjność wizualna, rozrywka, humor, agresja i przemoc, wulgaryzmy, niekontrolowana/nadmierna konsumpcja, negatywny obraz dorosłych, konflikty w grupie rówieśniczej, problemy rodzinne. Każdą z kategorii kodowało dwóch koderów, tak by móc porównać zwłaszcza kategorie ocenne. W poniższej tabeli opisano syntetycznie opis zakresu poszczególnych kategorii oraz metodę dokonywania oceny liczbowej.

Sumaryczne wyniki analiz zostały zaprezentowane w formie wykresów radarowych i zinterpretowane w kolejnej części artykułu. Na wykresach radarowych poszczególne krzywe prezentują uśrednione wyniki dla wszystkich badanych odcinków danej audycji (oceny wszystkich koderów). Wykresy syntetycznie, porównawczo prezentują wartości osiągnięte przez poszczególne audycje we wszystkich badanych kategoriach - o wysokiej jakości audycji świadczy wychy- 


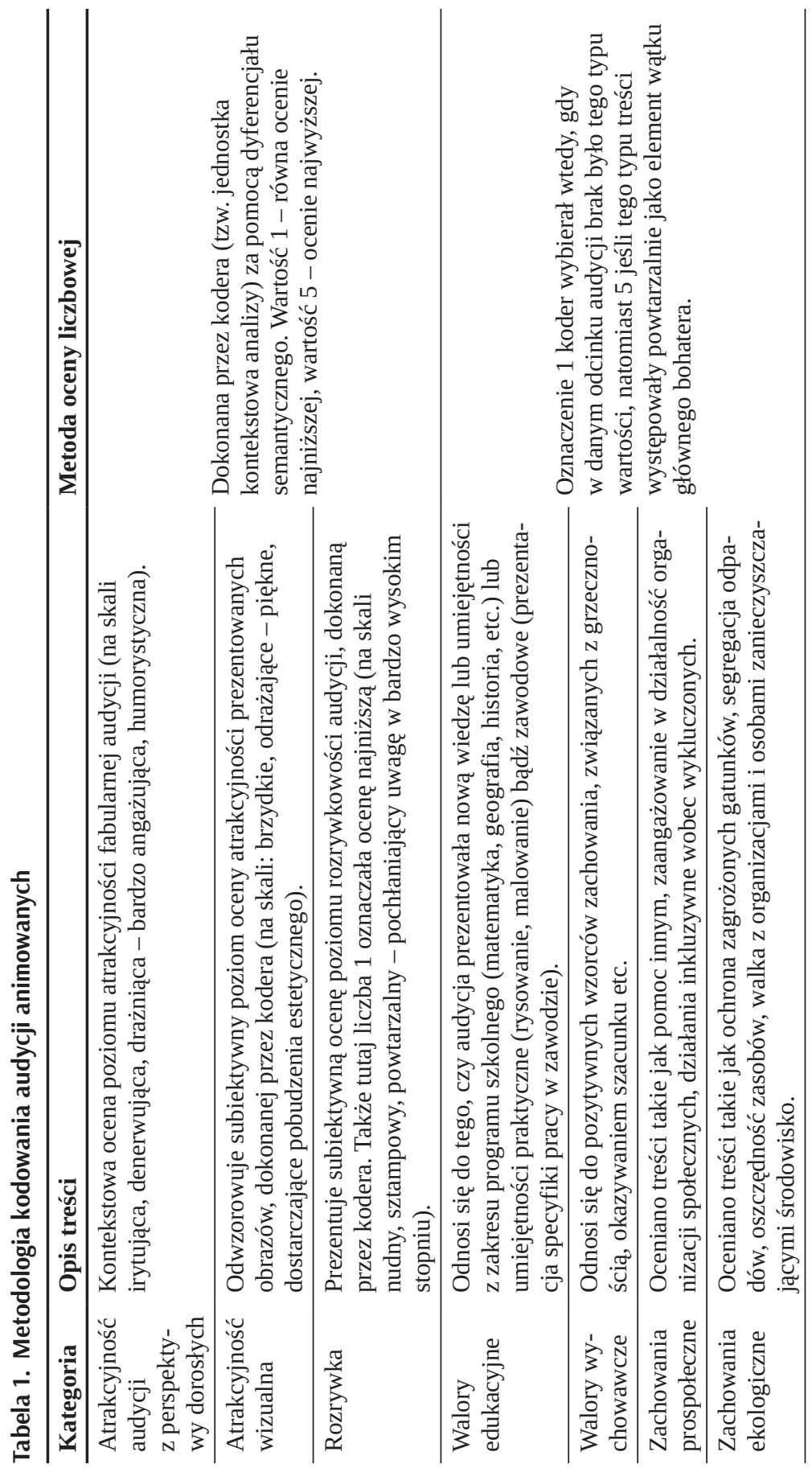




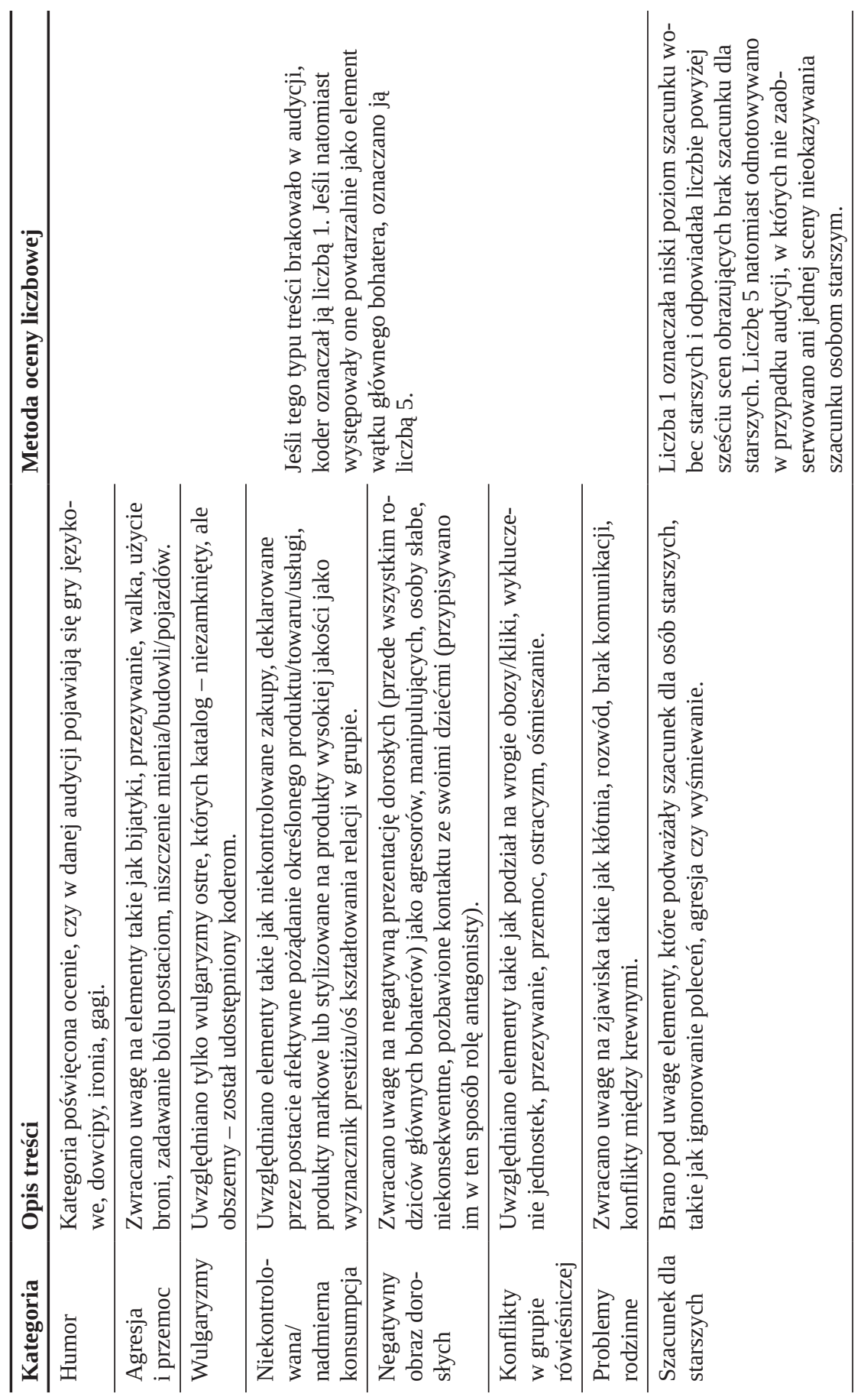


lenie krzywej na zewnątrz wykresu (do 5) w wartościach i treściach pozytywnych i wychylenie do wewnątrz wykresu (do 0) w wartościach i treściach negatywnych.

Warto podkreślić, że przedstawione wyniki obejmują część przeprowadzonych analiz (oprócz przedstawionych koderzy kodowali odcinki w 40 innych kategoriach $^{10}$ ). Niestety ze względu na ograniczenia objętościowe nie jest możliwe przedstawienie wszystkich wyników, dlatego też w niniejszym artykule autorzy skoncentrowali się na zaprezentowaniu kluczowych wymiarów świata przedstawianego w rzeczonych audycjach.

\section{WYNIKI BADANIA}

\section{MiniMini+}

Do analizy popularnego kanału MiniMini+ zakwalifikowano trzy audycje - „My Little Pony”, „Truskawkowe Ciastko” oraz „Ciekawski George”. „My Little Pony” to produkcja amerykańska firmy Hasbro Studios, kierowana do dzieci w wieku 3-8 lat. W tej bajce mamy do czynienia z bohaterem zbiorowym. Jest to mianowicie grupa kucyków-przyjaciółek, przeżywających wspólnie fantastyczne przygody w baśniowym świecie. Ta figura w sposób metaforyczny prezentuje grupy koleżeńskie złożone z dziewczynek. Wartości, jakie promowane są w audycji w sferze języka, fabuły oraz dyskursu rozumianego jako plan wyrażenia narracji to przyjaźń, piękno, odwaga, wrażliwość, życzliwość, pracowitość, opiekuńczość, pomoc innym. Postacie prezentują zachowania typowe dla grupy wiekowej wczesnoszkolnej, z silną estetyzacją postaci i wyraźną, archetypową konstrukcją czytelnych, pozytywnych wzorców osobowych (spójne postaci np.: Rainbow Dash - asertywna, odważna, lojalna; Fluttershy - nieśmiała, wycofana, życzliwa).

Zgodnie z krzywą zaprezentowaną na radarowym wykresie kanału MiniMini+ bajka „My Little Pony” uzyskała wysoką punktację w obszarze wartości prospołecznych, edukacyjnych, a także w kategoriach atrakcyjności i szacunku dla starszych. Program prezentuje bohaterki (kucyki pony) jako postacie pozytywne

10 Warto dodać, że podstawowym punktem odniesienia przy projektowaniu tej części klucza kodowego stanowiła koncepcja Władmira Proppa. Warto jednak wspomnieć, że tego typu ujęcie oczywiście na poziomie generalnym - odpowiada również późniejszym publikacjom dotyczącym bohaterów występujących w narracjach oraz narracyjnie traktowanych schematów uwzględnianych przy analizie mitów. Por. koncepcje M. Bal (2012), ale także C. Lévi-Straussa (2009) i J. Campbella (2013a, 2013b). 


\section{MiniMini+}

My Little Pony $\longrightarrow$ Truskawkowe Ciastko $\quad \longrightarrow$ Ciekawski George

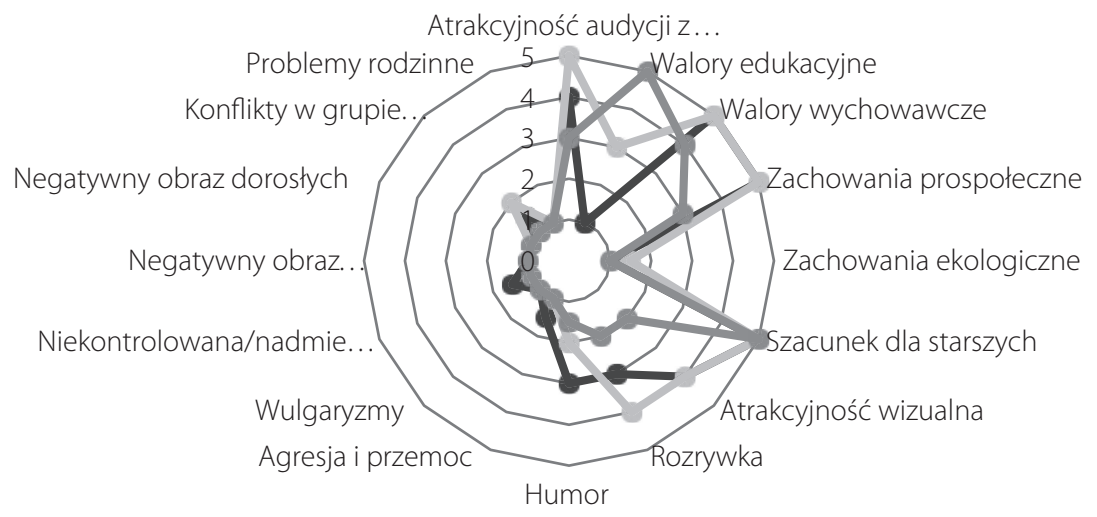

Wykres 1. Świat przedstawiony w audycjach kanału MiniMini+

Źródło: Opracowanie własne.

i potencjalny wzór do naśladowania. Program uzyskał wyraźnie niską wartość wskaźnika walorów edukacyjnych i poznawczych, głównie przez brak treści poszerzających wiedzę i rozumienie świata przez widzów (w całości fantastyczna metaforyczna - fabuła skupiona na przygodach i relacjach w grupie).

Kolejną bajką na kanale MiniMini+, którą poddano analizie, było „Truskawkowe Ciastko”, produkowane w USA przez MoonScoop Group, kierowane do tej samej grupy co „My Little Pony” - 3-8 lat. Bohater również jest zbiorowy. To także grupa dziewczynek w wieku przedszkolnym/wczesnoszkolnym, zaprzyjaźnionych ze sobą i tworzących przyjazne, spokojne relacje. Wartości promowane w zachowaniu bohaterów i przeżywanych perypetiach to: dociekliwość, zaradność, pomysłowość, kreatywność, przyjaźń, spokój, harmonia, pomoc innym. Postacie prezentują zachowania typowe dla grupy dziewczynek w wieku szkolnym, funkcjonujących w harmonijnym otoczeniu. Zauważalny w toku analizy jest relatywnie niski poziom konfliktu w grupie. Widoczny jest nacisk na pozytywne wzorce osobowe. Wart odnotowania jest fakt wysokiej oceny atrakcyjności wizualnej przedstawionego świata i bohaterek (kolorystyka, kształty, kontrasty etc.). Program uzyskał wysokie oceny w wymiarach dotyczących walorów wychowawczych, 
zachowań prospołecznych, szacunku dla starszych, a także w zakresie atrakcyjności (wizualnej oraz z perspektywy osób dorosłych), a także rozrywki. Taki profil wskazuje na to, że jest to program nastawiony na prezentację rozrywkowych historii w atrakcyjnej wizualnie formie i w oparciu o sylwetki interesujących bohaterów, nieepatujący nadto treściami edukacyjnymi, ale jednocześnie posiadający walory wychowawcze. Zgodnie z danymi zaprezentowanymi na wykresie $\mathrm{nr} 1$ audycji przypisano negatywne wskazania jedynie w analizie sposobu prezentacji konfliktów w grupie bohaterek.

Ostatnią bajką, jaką poddano analizie na kanale MiniMini+, był „Ciekawski George” - to audycja również produkowana w USA, przez Universal Animation Studios, Imagine Entertainment oraz WGBH Boston, przeznaczona dla dzieci w wieku 3-5 lat. W tej bajce mamy do czynienia z bohaterem indywidualnym Georgem, ciekawską małpką, która w nieco chaotyczny sposób poznaje otaczający ją świat. Promowane wartości, które odnotowali koderzy to: dociekliwość, ciekawość świata, chęć eksperymentowania, odwaga, zaradność, niezależność. Bohater bajki prezentuje zachowania eksploracyjne i sposób uczenia się charakterystyczny dla małego dziecka (2-4 lata), jego zachowanie stanowi naturalny wzorzec rozbudzający ciekawość świata i zainteresowanie otoczeniem u dzieci z rzeczonej grupy docelowej. Audycja ta została bardzo wysoko oceniona pod względem walorów edukacyjnych, wychowawczych oraz szacunku dla starszych, co w połączeniu z grupą wiekową odbiorców audycji pozwala zaklasyfikować ten program jako dydaktyczną audycję dla młodszych widzów, bez bardzo silnego akcentu na element rozrywkowy i poczucie humoru. Audycja ta została także zakodowana jako średnio atrakcyjna z perspektywy osób dorosłych - jest ona stosunkowo mało uniwersalna i skierowana do precyzyjnie wyznaczonej grupy wiekowej.

Podsumowując wyniki dla kanału MiniMini+, analizowanego przez pryzmat wspomnianych trzech bajek, warto zaznaczyć, że na wykresie nr 1 zauważalne jest wyraźne wychylenie krzywych radarowych w kierunku pozytywnych, pożądanych wartości i postaw. Należy podkreślić, iż wszystkie trzy audycje w znacznej mierze otrzymały najwyższe oceny w najważniejszych, jak się wydaje, z punktu widzenia rodzica, kategoriach: walory wychowawcze, zachowania prospołeczne i szacunek dla starszych. Dość wysoko oceniona została również ich atrakcyjność (zarówno całościowa, jak i wizualna). To, na co warto jeszcze zwrócić uwagę, to widoczne rozbieżności pomiędzy krzywymi w kategorii „walory edukacyjne”. Rozpiętość tej skali w przypadku badanych audycji wynika - tak jak już wskazywano wcześniej - z relatywnie niższych ocen bajek „My Little Pony” oraz „Truskawkowe ciastko” w zakresie walorów edukacyjnych niniejszych narracji. Na tym tle „Ciekawski 
George”, kierowany do młodszej grupy wiekowej, wyraźnie odstaje in plus. Jeśli chodzi o negatywne wymiary analizowanych audycji, to należy stwierdzić, że nie uzyskały one wyraźnej, negatywnej punktacji na żadnym z wymiarów, z nieznacznymi jedynie wychyleniami w kierunku agresji, prezentacji zachowań konsumpcyjnych (ostentacyjne pożądanie biżuterii w jednym z analizowanych odcinków) i konfliktów w grupie bohaterów.

\section{TeleTOON+}

Kolejnym kanałem, który wzięto na warsztat, był TeleTOON+. Tutaj także wybrano trzy audycje. Pierwsza - „Supa Strikas” - to nowa bajka w ofercie TeleTOON+, produkowana w Malezji przez Animasia Studio, kierowana do grupy wiekowej 8-12 lat. W tej audycji mamy do czynienia z bohaterem zbiorowym - grupą piłkarzy-gwiazdorów, rywalizujących w zawodach sportowych i innych dziedzinach życia. Odkodowane, promowane w audycji wartości to: relacje grupowe, rywalizacja (także nieustępliwość), przyjaźń, rozwój zdolności bohaterów, sukces, kształtowanie charakteru bohaterów. Postacie prezentują zachowania typowe dla grupy chłopięcej w wieku 10-15 lat (zdaniem współpracującego z grupą badawczą psychologa rozwojowego - starszej niż grupa docelowa audycji) stanowiącej potencjalną grupę odniesienia dla widzów.

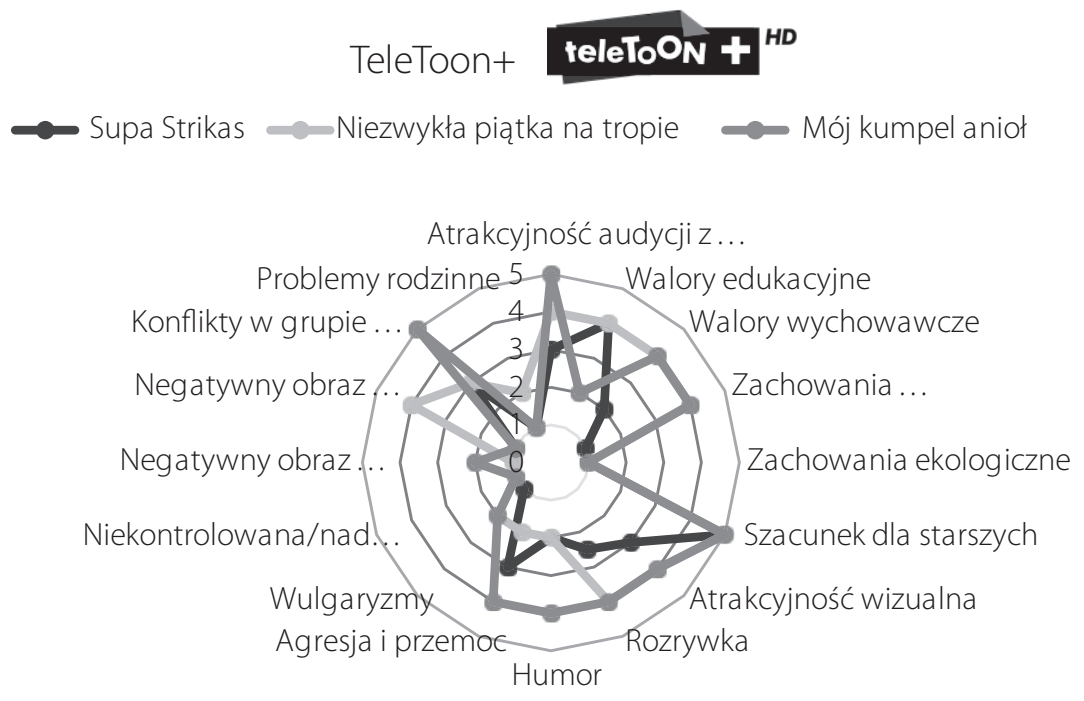

Wykres 2. Świat przedstawiony w audycjach kanału TeleTOON+ Źródło: Opracowanie własne. 
Spoglądając na krzywą radarową dla niniejszej audycji, można łatwo zaobserwować, że otrzymała ona wysokie wskazania w kategoriach „walory edukacyjne” i „szacunek dla starszych”, jednocześnie została jednak nisko oceniona na skali walorów wychowawczych i zachowań prospołecznych (prezentuje zachowania silnie rywalizacyjne w grupie bohaterów). Audycja otrzymała też stosunkowo wysokie wartości wskaźników dotyczących agresji i przemocy oraz konfliktów w grupie - prezentuje ona środowisko młodych sportowców, które cechuje się wysokim poziomem sporów w grupie oraz wysoką rywalizacją (nieustępliwością).

Kolejna audycja to „Niezwykła piątka na tropie”, bajka produkowana przez międzynarodową koalicję producencką - dokładnie francusko-brytyjską - Marathon Media Group, Chorion, Disney Europe, France 3, i przeznaczona dla dzieci w wieku 6-9 lat. Bohater jest również zbiorowy - grupa przyjaciół rozwiązująca zagadki kryminalne i rywalizująca z przeciwnikami (à la „Scooby Doo i Brygada Detektywów”). Eksponowane wartości to dociekliwość, umiłowanie przygody, samodzielność, swoboda, przyjaźń, odwaga. Postacie tworzą zgraną grupę przyjaciół, która wspólnie rozwiązuje zagadki kryminalne i przeżywa przygody. Widoczne, odnotowane przez koderów, połączenie aspektu relacyjnego z atrakcyjną, obfitującą w wyzwania fabułą, wzmacnia wyrazistość i spójność grupy bohaterów. Dziewczęta są dojrzalsze emocjonalnie od chłopców. Ponadto zaczyna pojawiać się kontekst zainteresowania chłopcami ze strony dziewcząt (chłopcy najczęściej tego nie dostrzegają albo są skonfundowani, zawstydzeni, wycofani). Bajka otrzymała wysokie wskazania praktycznie we wszystkich kategoriach poza humorem oraz zachowaniami ekologicznymi, co wskazuje na jego stosunkowo wyważoną fabułę i atrakcyjny sposób konstrukcji opowieści w audycji. Jednakże wraz z wysokimi wskaźnikami pozytywnymi, bajka otrzymała także wysoką punktację negatywną w obszarach takich jak negatywny obraz osób dorosłych (nie jest to wymiar tożsamy z szacunkiem dla starszych - obraz dorosłych dotyczy ich zachowań prezentowanych w audycji, a szacunek do starszych zachowań bohaterów wobec dorosłych), a także konflikty w grupie i problemy bohaterów, jak też nieznacznie wyższe natężenie tzw. miękkich wulgaryzmów (np. kurde, cholerka).

Ostatnią audycją kanału TeleTOON+, która została zakwalifikowana do badania, jest „Mój przyjaciel anioł”, kanadyjskiej firmy Temple Street Productions, kierowana do grupy wiekowej 10-13 lat. Głównymi bohaterami są Carl Montclaire, chłopak, który - wydaje się - ma w życiu ogromnego pecha i jest wciąż nieszczęśliwy, oraz jego przyjaciel - anioł, zesłany na ziemię Porter Jackson. Zakodowanymi, promowanymi wartościami w audycji są: przyjaźń, odwaga, pewność siebie, przełamywanie własnych ograniczeń, a także poczucie humoru. Program w wyraźny sposób prezentuje uniwersalne kwestie, takie jak rozwój 
osobisty, dojrzewanie, budowa rozsądnych relacji z grupą i poszukiwanie pozycji w środowisku szkolnym. Serial ten został wysoko oceniony pod względem wartości rozrywkowych, jak też walorów wychowawczych i prezentacji zachowań prospołecznych. Podobnie jak „My Little Pony” jest to program, który prezentuje atrakcyjnych, pozytywnych bohaterów, rezygnując jednak z eksponowania treści edukacyjnych. Wyraźnym problemem w serialu - co pokazuje jednoznacznie krzywa na wykresie radarowym 2 - jest bardzo wysoki poziom konfliktów rówieśniczych i agresji prezentowany w programie; dodatkowo w programie została zauważona także wyraźnie większa niż w innych audycjach obecność tzw. miękkich wulgaryzmów oraz negatywny obraz systemu edukacji (szkoła, nauczyciele, dyrekcja).

Podsumowując, wykres radarowy dla kanału TeleTOON+ zwraca uwagę rozbieżnością ocen w audycjach tej samej stacji. Zbliżone wartości wszystkie trzy produkcje mają tylko w kategorii „atrakcyjność audycji z perspektywy dorosłych” i „szacunek dla starszych”. Niepokojąco wysokie są noty w kategorii „konflikty rówieśnicze” oraz „agresja” i „przemoc”.

\section{Nickelodeon}

Z kanału Nickelodeon zakwalifikowano do badania cztery audycje. Pierwsza z nich - „Marvin Marvin” - to amerykańska produkcja The Collective i Nickelodeon Productions, kierowana do dzieci w wieku 12-14 lat. W tym sitcomie mamy do czynienia z indywidualnym głównym bohaterem, którym jest kosmita w ciele nastolatka Marvina. Promowane w audycji wartości to spontaniczność, życzliwość, swoboda, dociekliwość, a także ekscentryzm. Bohater spełnia w fabule w znacznej mierze funkcję humorystyczną i raczej nie stanowi wzorca osobowego dla grupy docelowej programu w ścisłym tego słowa znaczeniu - jest to raczej kreacja humorystyczna (by nie powiedzieć komiczna, przerysowana), podana w określonej konwencji (sitcom), niż prezentująca konkretne cechy do naśladowania. Audycja ta otrzymała wysokie wskaźniki w obszarach rozrywki, humoru i atrakcyjności wizualnej, a także stosunkowo wysoką ocenę walorów wychowawczych i zachowań prospołecznych. Wyraźnym problemem są tu z pewnością bardzo swobodne, liberalne relacje między postacią bohatera a osobami dorosłymi, przez co audycja wyraźnie odstaje w tym zakresie od polskiej perspektywy interakcji na linii rodzic - dziecko (sposób zwracania się do siebie, żartowania, a także kłócenia się). Wyraźnymi problemami tej audycji są prezentowane w niej konflikty w grupie bohaterów, a także nieco wyższy niż minimalny poziom agresji i przemocy między bohaterami. 


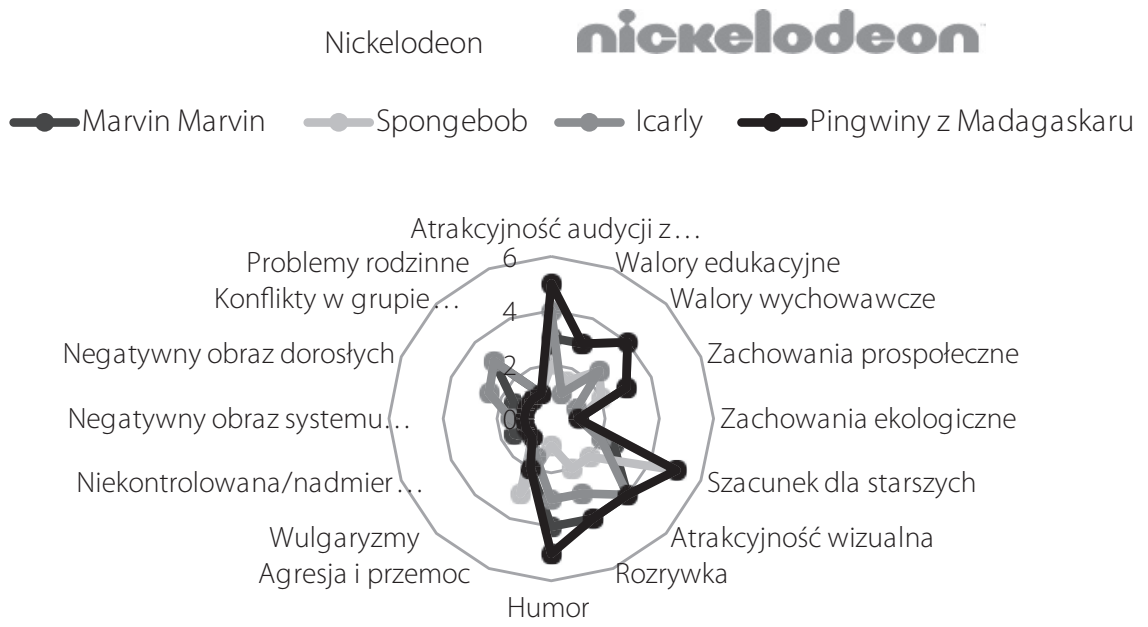

Wykres 3. Świat przedstawiony w audycjach kanału Nickelodeon Źródło: Opracowanie własne.

Kolejna audycja to „Spongebob” - wyprodukowana w USA przez United Plankton Pictures oraz Nickelodeon Animation Studios, skierowana do grupy wiekowej 6-11 lat. Bohaterem, indywidualnym, bajki jest tytułowy Spongebob, animowany stwór (ożywiona gąbka, nosząca spodnie). Promowane, zakodowane wartości to pracowitość i uczynność. Postać bohatera często znajduje się w roli kozła ofiarnego, to potencjalny antywzorzec (nikt nie aspiruje do takiej roli, ale może prezentować zachowania poniżające i wykorzystujące słabszych i młodszych). To, co trzeba podkreślić, to fakt, że audycja została bardzo nisko oceniona w praktycznie wszystkich wymiarach (oprócz szacunku do starszych), co może wynikać z celowego zabiegu operowania w jej przypadku groteską i antyestetyką w prezentacji bohaterów i świata (zamierzona deformacja świata przedstawionego?). Jedynym, szczególnie wyraźnie widocznym problemem tej audycji - zgodnie z krzywą zaprezentowaną na wykresie radarowym 3 - jest kwestia poziomu przemocy. Zauważyć jednak należy, że ma ona charakter abstrakcyjny i rysunkowy, stosunkowo mało realistyczny.

Przedostatnią audycją kanału Nickelodeon, która została zakwalifikowana do badań, jest „iCarly”, produkcji amerykańskiej Schneider’s Bakery oraz Nickelodeon Productions, dla grupy wiekowej 12-14 lat. Na pierwszy rzut oka mamy w tym sitcomie do czynienia z bohaterem indywidualnym, Carly Shay, jednak w każdym odcinku można obserwować perypetie całej trójki (prócz Carly Shay, także Sam Puckett i Freddiego Bransona) przyjaciół wspólnie tworzącej popularny 
webcast - „iCarly” - transmitowany w internecie (bohater zbiorowy - twórcy „iCarly”). Promowane w audycji wartości to: popularność (rozpoznawalność), humor, entuzjazm, życzliwość, pewność siebie, asertywność. Postacie prezentują zachowania osób z grupy w wieku wczesnogimnazjalnym, są atrakcyjne (popularne, posługujące się nowinkami technologicznymi), samodzielne, mogą stanowić silny wzorzec dla oglądających program. Audycja została stosunkowo wysoko oceniona w obszarze wartości rozrywkowych, humoru i atrakcyjności, jednocześnie będąc nisko ocenianą w obszarach szacunku do starszych (stosunek bohaterki do osób dorosłych), walorów edukacyjnych oraz zachowań prospołecznych - tu audycji przypisano jeden z niższych wyników w całej próbie. W analizie audycji wyraźnymi, choć wcale nie tak znowu silnymi (w przeciwieństwie np. do audycji na kanale Cartoon Network - zob. dalej) problemami były kwestia konfliktów w grupie rówieśniczej oraz negatywny obraz dorosłych.

Ostatnia audycja zakwalifikowana do analizy w ramach kanału Nickelodeon to „Pingwiny z Madagaskaru” produkcji amerykańskiej DreamWorks Animation oraz Nickelodeon Animation Studio. W przypadku tej audycji trudno określić przedziałową grupę wiekową. Jest to bowiem audycja z tzw. uniwersalną grupą docelową - ze względu na atrakcyjność fabularną, dramaturgiczną, humorystyczną oraz wizualną. W rzeczonej audycji bohater jest zbiorowy. Jest to grupa zwierząt mieszkających w nowojorskim zoo (główny jednak akcent położony jest na tytułową grupę pingwinów). Promowane, zakodowane w toku badania, wartości to: przyjaźń, zaradność, spryt, elastyczność, umiejętność rozwiązywania problemów, dociekliwość, umiejętności techniczne, wysportowanie. Postaci prezentują zachowania uniwersalne, w konwencji humorystycznej pokazujące współpracę w grupie i wspólne przygody. W audycji silnie akcentowany jest humor, postacie mogą stanowić wzorzec zachowania dla młodszych odbiorców (8-10 lat). Audycja relatywnie bardzo dobrze oceniana jest przez dorosłych w grupie (18-24). Wydaje się, że mamy tutaj do czynienia z tzw. zjawiskiem kidults/adulthood/adulescent/ rejuvenile - dzieciorosłych (à la „Shrek”, 2001, reż. A. Adamson, V. Jenson) ${ }^{11}$. Jest to jedna z sumarycznie najwyżej ocenionych audycji w badaniu, uzyskująca wysokie lub średnie wyniki na prawie wszystkich wskaźnikach. Audycja nie wykorzystuje jednak potencjału tematycznego (zwierzęta, zoo) do poruszenia kwestii ekologicznych, stąd też, tak jak pozostałe programy w badaniu, ma bardzo niską ocenę w tym wymiarze. Jest to także jedna z najbardziej uniwersalnych

11 Zob. w szczególności Noxon Ch. (2006). Rejuvenile: Kickball, Cartoons, Cupcakes, and the Reinvention of the American Grown-up. New York: Broadway Books oraz Brooks K. (2003); Nothing sells like teen spirit: the commodification of youth culture. W: K. Mallan, S. Pearce (red.), Youth cultures, texts, images, and identities (s. 1-16). London: Praeger. 
audycji, atrakcyjna zarówno dla osób dorosłych, jak i dzieci. Jedynym wyraźniej widocznym problemem tej audycji jest kwestia poziomu przemocy. Trzeba jednak zauważyć, że ma ona charakter abstrakcyjny i rysunkowy, stosunkowo mało realistyczny i stanowiący element komediowy (często z wykorzystaniem mechanizmów typowych dla komedii slapstickowej).

Podsumowując, wyróżniającą wśród badanych audycji kanału Nickelodeon jest bajka „Pingwiny z Madagaskaru”, która z powodzeniem zdobywa życzliwą uwagę dorosłych (wysokie noty w kategoriach „atrakcyjność audycji z perspektywy dorosłych” i „humor” - tu, jak wynika z analizy jakościowej, często bazujący na ironii, polisemii, czasem interseksualności, a więc elementach zrozumiałych dla odbiorców o rozbudowanej kompetencji komunikacyjnej). Trzeba też podkreślić znacząco niskie noty dla „Spongeboba” (prócz kategorii szacunek dla starszych).

\section{Disney Junior}

Na kanale Disney Junior badano trzy audycje. Pierwsza z nich to „Podróże Justina”, amerykańskiej produkcji Guru Studio, przeznaczona dla grupy wiekowej 5-7 lat. Bohaterem jest tytułowy Justin, chłopiec w wieku ok. 6 lat, który przeżywa różne przygody. Promowane wartości to: dociekliwość, ciekawość świata, chęć do zabawy, optymizm. Bohater stanowi kapitalny punkt odniesienia raczej dla młodszych odbiorców - w wieku ok. 4-5 lat, z racji dość uproszczonego, naiwnego zachowania, nie do końca typowego dla dziecka w wieku wczesnoszkolnym. Jak pokazuje krzywa audycji wyrysowana na wykresie radarowym 4, jest to jeden z nielicznych programów o wysokich walorach edukacyjnych, który jednocześnie uzyskał ocenę przynajmniej trzech punktów w wymiarach takich jak rozrywka czy atrakcyjność wizualna, co czyni go programem bardzo atrakcyjnym z perspektywy rodzica, bo realizującym zarówno funkcję rozrywkową, jak i edukacyjno-wychowawczą. Co warto podkreślić, audycja nie otrzymała żadnych punktów w negatywnych kategoriach, co wyraźnie widać na wykresie 4.

Kolejną zanalizowaną audycją jest „Art Attack”, produkcji brytyjskiej - The Walt Disney Company, kierowana do grupy wiekowej 7-13 lat. W tym programie brak bohatera. Audycja ma charakter niefabularny, z prowadzącym prezentującym różne praktyczne projekty plastyczne, które widzowie mogą wykonywać samodzielnie - to rodzaj „telewizyjnego ZPT”. Program skupia się raczej na prezentacji konkretnych technik wymagających współpracy z rodzicem niż na osobie prowadzącego, stąd można powiedzieć, że nie jest on sensu stricto wzorcem osobowym dla młodych widzów. Program ten spełnia przede wszystkim rolę edukacyjną - rozwijającą kompetencje plastyczne i sprawność manualną młodych 


\section{Disney Junior DisNeYY.}

$\longrightarrow$ Podróże Justina —Art. Attack —Jej Wysokość Zosia

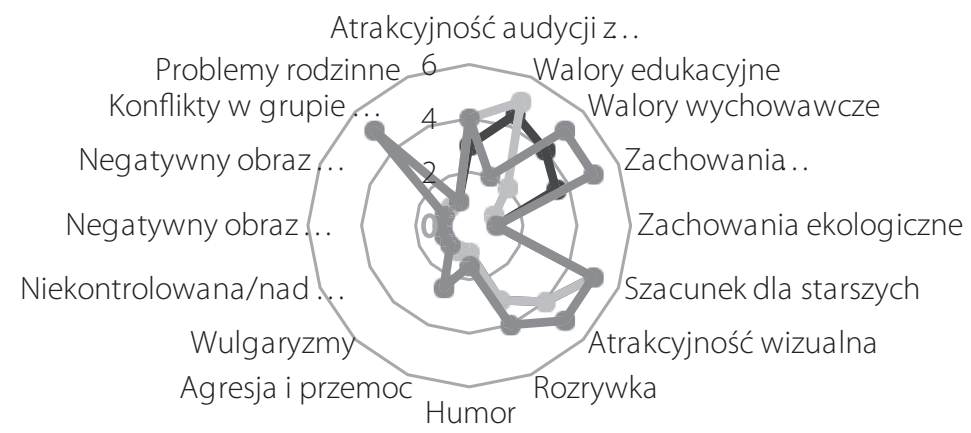

Wykres 4. Świat przedstawiony w audycjach kanału Disney Junior

Źródło: Opracowanie własne.

widzów, w mniejszym stopniu odwołując się do kwestii wychowawczych czy zachowań prospołecznych (jeśli już, to jednak w kontekście pomocy starszych dorosłych - w pracach plastycznych, promowanie współtworzenia z rodzicami różnych dzieł plastycznych, technicznych, artystycznych). Co istotne - ta audycja również nie otrzymała żadnych negatywnych wskazań.

Ostatnią audycją zakwalifikowaną do badania z kanału Disney Junior jest „Jej Wysokość Zosia”. To bajka produkcji amerykańskiej Disney Television Animation oraz Disney Junior Originals, kierowana do dzieci w wieku 5-8 lat. Główną jej bohaterką jest tytułowa księżniczka Zosia. Promowane w bajce wartości to: życzliwość, sprawiedliwość, wrażliwość, koleżeństwo, otwartość na innych ludzi, troska o innych, empatia. Postać prezentuje cechy archetypowe dla postaci baśniowej księżniczki, jest też bardzo wystylizowana i dopracowana estetycznie - przedstawia bardzo spójny zestaw cech charakteru i wyglądu. Może oddziaływać silnie jako wzorzec osobowy dla młodszych dziewczynek. Podobnie jak „My Little Pony” jest to program osiągający wysokie wyniki w obszarach rozrywki i atrakcyjności wizualnej, a także prezentacji wzorców osobowych i zachowań prospołecznych. Program ten może stanowić atrakcyjną rozrywkę niepozbawioną walorów wychowawczych (wyraźne, pozytywne postaci), nie ma jednak wielu walorów czysto poznawczych. W tym i niektórych innych programach skierowanych do dziewczynek widoczny jest wysoki poziom konfliktu i rywalizacji w grupie 
rówieśniczej, a także nieco wyższy od minimalnego poziom agresji (chodzi tu raczej o złość).

Podsumowując kanał Disney Junior przez pryzmat zbadanych audycji, można stwierdzić, że otrzymał ona najlepsze noty (obok MiniMini+) w porównaniu do pozostałych kanałów. To, co warto odnotować, to wysokie noty bajki „Jej Wysokość Zosia”, która rzeczywiście wskazywana była przez koderów jako lider w wielu wymiarach. Trzeba też zwrócić uwagę, że niemało punktów przyznano jednak rzeczonej bajce w wymiarze konfliktów rówieśniczych. Spoglądając na wykres 4, łatwo zauważyć dosyć dużą zbieżność w ocenie wszystkich trzech audycji - zwłaszcza w wymiarach: szacunek dla starszych, atrakcyjność wizualna czy rozrywka. Wyróżniającą się ze wszystkich zakwalifikowanych do próby audycją, jest - ze względu na swoją formułę - Art Attack. Formuła tej audycji wyraźnie odstaje od pozostałych, przez co również otrzymała ponadprzeciętne wyniki punktowe w wymiarze walorów edukacyjnych. Niestety w porównaniu do pozostałych audycji uczy tylko umiejętności manualnych przy pomocy dorosłych, choć czyni to w dość atrakcyjny wizualnie sposób.

\section{Disney Channel}

Na kanale Disney Channel analizowano trzy audycje. Pierwsza z nich to niezwykle popularna wśród dziewczynek „Violetta”, produkcji argentyńskiej - Polka Producciones - kierowana do grupy wiekowej 12-16 lat (tutaj w sposób szczególny warto podkreślić, że w przypadku audycji kierowanych do dzieci mamy do czynienia z tzw. drabiną wiekową, która polega na tym, iż audycje kierowane do określonej grupy wiekowej są przede wszystkim oglądane przez dzieci o kilka lat - 2-3 lata - młodsze, zaś te z grupy, dla których audycja jest przeznaczona, coraz częściej uważają, iż dana audycja jest passé lub wprost, że jest „dla dzieci” w domyśle: młodszych dzieci, młodszych nastolatków). Bohaterem audycji jest tytułowa młoda piosenkarka Violetta. Promowane, zakodowane przez koderów audycji, wartości to: życzliwość, otwartość na innych, troskliwość, szczodrość, talent, pracowitość, ale również spryt i zaradność. Postać główna (ale również jej towarzyszące) ma kilkanaście (16-19) lat, prezentuje wiele cech atrakcyjnych dla grupy docelowej serialu - wysoki status materialny, niezależność, talent, popularność, ale jest także samotnie wychowywana przez zaborczego ojca-wdowca. Dla młodszych odbiorczyń może być silnym wzorcem osobowym i punktem odniesienia. Jest to program wysoko oceniony na prawie wszystkich wymiarach (wynik przynajmniej trzech punktów w ośmiu z dziewięciu kategorii). Program operuje atrakcyjną formą i ma spore walory rozrywkowe, z jednoczesną wyraźną 
prezentacją pozytywnej postaci głównej, która przeżywa różne rozterki i jest uwikłana w rozliczne perypetie - miłosne, towarzyskie, szkolne, zawodowe, rodzinne etc. Problemem bardzo mocno widocznym w przypadku tej audycji jest krańcowo wysoki poziom konfliktów w prezentowanej w nim grupie rówieśniczej, jak też połączenie tego obrazu z widocznymi problemami rodzinnymi i negatywnym, oderwanym od rzeczywistości i przerysowanym obrazem osób dorosłych. Dorośli są w audycji karykaturalni, popadający w skrajności, często nieracjonalni, silnie targani przeciwstawnymi emocjami.

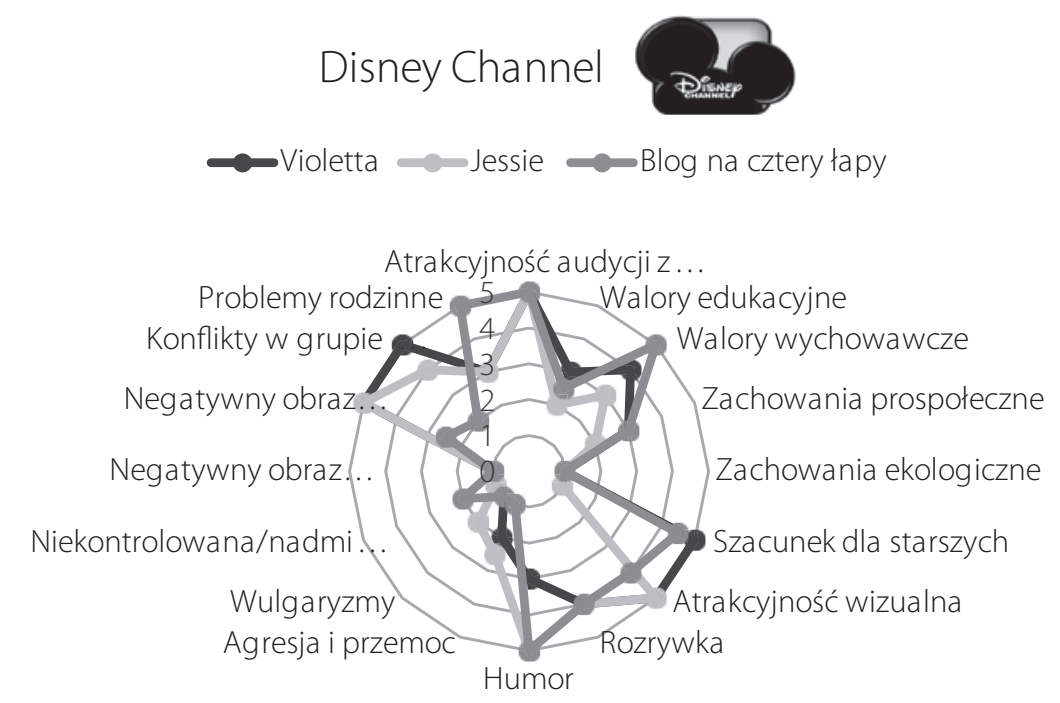

Wykres 5. Świat przedstawiony w audycjach kanału Disney Channel Źródło: Opracowanie własne.

Drugą audycją poddaną badaniu była amerykańska produkcja firm It’s a Laugh Productions, Bon Mot Productions oraz Disney Channel Original Productions „Jessie” - przeznaczona dla grupy wiekowej 8-16 lat. Bohaterką jest tytułowa Jessie, młoda, przebojowa, wygadana dziewczyna, opiekunka trójki młodszych dzieci. Promowane w audycji wartości to: życzliwość, otwartość na innych, empatia, prostolinijność, inteligencja, śmiałość, humor, rozwaga, przemyślność, ale także spontaniczność. Jessie to postać nastoletnia (ma ok. 17-20 lat), pełna humoru, naturalna, prostolinijna, z dystansem do rzeczywistości, nastawiona na relacje z innymi ludźmi. Stanowi bardzo ciekawy wzorzec osobowy dla młodych widzów - nieszablonowy, niepretensjonalny. Program ten został wysoko oceniony 
pod kątem humoru, atrakcyjności wizualnej i walorów rozrywkowych, osiągając jednak bardzo niską wartość na osi szacunek dla starszych. Niezbyt wysoko ocenione zostały także walory edukacyjne. Problemem tej audycji jest, podobnie jak w przypadku innych produkcji Disney Channel, wysoki poziom konfliktów w grupie rówieśniczej i problemów rodzinnych bohaterki, połączony ze skrajnie negatywnym, przejaskrawionym obrazem osób dorosłych (jak w „Violetcie”).

Ostatnią badaną audycją na kanale Disney Channel był „Blog na cztery łapy”, produkcji amerykańskiej firm Diphthong Productions oraz It's a Laugh Productions, nieprzeznaczona dla szczególnej grupy wiekowej (format sitcomowy à la „Bill Cosby Show”, dla młodszej jednak widowni). Bohater jest zbiorowy - to nastoletnie rodzeństwo żyjące w dużej rodzinie z psem. Eksponowane wartości to: humor, relacje rodzinne, inteligencja, emocjonalność. Postaci żyjące w humorystycznie przedstawionej rodzinie są pełne humoru, spontaniczności, momentami silnie przerysowane. Fabuła jest realizowana w wyraźnej konwencji komediowej. Można zaobserwować relatywnie niski poziom realizmu i traktowania postaci jako punktu odniesienia przez widzów. Program został bardzo wysoko oceniony na prawie wszystkich obszarach (z wyjątkiem zachowań ekologicznych i walorów edukacyjnych) i wskazany jako drugi, obok „Pingwinów z Madagaskaru”, program odbierany jako uniwersalny - atrakcyjny i dla dzieci, i dla dorosłych. Problemem w tym sitcomie jest bardzo silny i wyraźny motyw skomplikowanych relacji rodzinnych bohaterów, który stanowi dominujący komponent fabuły większości odcinków i powiązany jest ze stosunkowo negatywnym, przerysowanym obrazem osób dorosłych w programie.

Podsumowując, zauważalna na wykresie radarowym jest istotna zbieżność wszystkich trzech audycji w kategoriach „humor” i „atrakcyjność wizualna”. Generalnie nisko oceniono w rzeczonych audycjach walory edukacyjne (we wszystkich trzech audycjach). Należy podkreślić silne akcentowanie w fabułach problemów rodzinnych i konfliktów w grupie rówieśniczej - ale to także może być pochodną faktu, że audycje są przeznaczone dla nieco starszej grupy docelowej w porównaniu do pozostałych kanałów.

\section{Cartoon Network}

Ostatni w badaniu jest Cartoon Network, kanał, który - obok Disney Junior i Disney Channel - nie posiada polskiej koncesji nadawczej Krajowej Rady Radiofonii i Telewizji, przez co jest tzw. kanałem zdelokalizowanym, to znaczy zarejestrowanym w innym kraju Unii Europejskiej, jednak skierowanym do polskiego widza. W związku z tym nie jest objęty polską jurysdykcją ani kontrolą KRRiT 


\section{Cartoon Network CARTOON NETWORK}

-Ben 10 Omniverse $\longrightarrow$ Scooby Doo i Brygada Detektywów $\longrightarrow$ Plan totalnej porażki

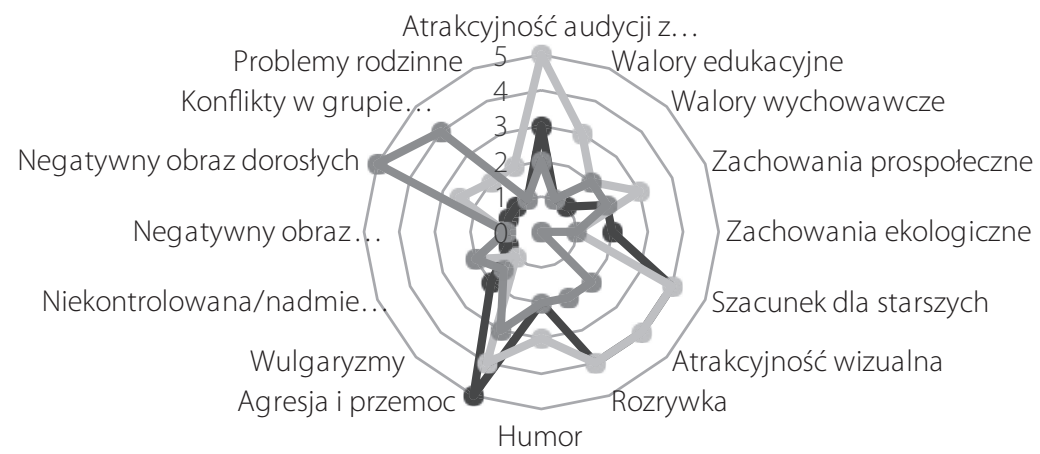

Wykres 6. Świat przedstawiony w audycjach kanału Cartoon Network

Źródło: Opracowanie własne.

(Gackowski i in., 2012). Jest to dość istotne, ponieważ Caroon Network wielokrotnie wzbudzał wątpliwości i kontrowersje wśród rodziców, śledzących audycje oglądane przez ich dzieci właśnie na tym kanale ${ }^{12}$.

Pierwszą analizowaną audycją z oferty Cartoon Network był serial animowany „Ben10 Omniverse”, produkcji amerykańskiej Cartoon Network Studios, przeznaczony dla grupy wiekowej 11-14 lat. Bohaterem bajki jest legendarny dla wielu chłopców tytułowy Ben, nastolatek wyposażony w techniczne gadżety i wynikające z nich supermoce, tak, jak możliwość zmieniania się w różne kosmiczne kreatury, które potrafią zwyciężyć w walce z innymi potworami. Promowane wartości to: sprawność fizyczna, zaradność, pomysłowość, rezolutność, ale również egotyczność, pycha. Fabuła jest mocno skupiona na głównym bohaterze, jego zmaganiach z przeciwnikami, fantastycznych przygodach i rozwoju jego możliwości. Można założyć silną identyfikację młodszych widzów (chłopców) z bohaterem. Kreskówka „Ben 10 Omniverse” należy do programów ocenionych wysoko pod względem walorów rozrywkowych i atrakcyjności wizualnej, ale jednocześnie nieposiadających wysokich walorów wychowawczych czy edukacyjnych. Jest to

12 Zob. http://wyborcza.pl/duzyformat/1,127291,5693212,Jak_Jasiek_zaprzyjaznil_sie_z_idiota. html oraz dyskusje na forach dziecko-info.rodzice.pl czy wielodzietni.net. [dostęp: 21.03.2015]. 
typowy przykład kreskówki fantastycznej, z fabułą w konwencji science-fiction, skupioną na przygodach głównego bohatera i na samym bohaterze. Program jest marką legendarną już dla młodszej widowni - zwłaszcza chłopców (dostępna jest bogata gama gadżetów poszerzających uniwersum marki - zabawek, gier, komiksów). Kluczową osią fabularną programu jest walka bohatera z wrogami. Agresywne zachowania i sytuacje, w których w kreskówce prezentowana jest przemoc, są jednym z głównych elementów narracji - akceptowalnym, a nawet pożądanym środkiem zdobywania tego, czego pragnie główny bohater. Narzędzia realizacji planów to siła, krzyk, przemoc. Zwraca uwagę częste używanie wulgaryzmów i kolokwializmów („kurde”, „spadaj”, ale również „cholera”, „idiota”, „palant”), a także bezpośrednie zwracanie się do dorosłych, tak jakby przynależeli do grupy rówieśniczej. Język audycji jest niezwykle prosty, np. często pojawiają się równoważniki zdań. Trzeba też podkreślić najwyższy spośród wszystkich audycji poddanych badaniu wskaźnik agresji.

Kolejna audycja poddana analizie na Cartoon Network to bajka z bohaterem znanym wielu pokoleniom odbiorców - „Scooby Doo i Brygada Detektywów” amerykańskiej produkcji Warner Bros. Animation, przeznaczona dla grupy wiekowej 10+ (nastolatki). Bohater jest zbiorowy - to grupa przyjaciół i tytułowy pies Scooby Doo (który funkcjonuje w bajce na takich samych prawach, co reszta bohaterów-ludzi), rozwiązująca zagadki kryminalne i rywalizująca z przeciwnikami. Promowane wartości to: dociekliwość, przyjaźń, współpraca, racjonalny ogląd rzeczywistości, wsparcie członków grupy. Postacie prezentujące zachowania osób z grupy wiekowej 16-20 lat, z dynamiką relacji grupowych charakterystyczną dla starszych i dojrzalszych osób, mogą być odbierane jako punkt odniesienia dla zdecydowanie młodszej niż prezentowana w programie grupy wiekowej (zjawisko wspomnianej już tzw. drabiny wiekowej). Audycja ta to klasyka gatunku, budująca markę Scooby Doo (łączącą pokolenia). Warto odnotować silne wychylenie krzywej tej audycji na wykresie radarowym 6 w stronę m. in. atrakcyjności audycji dla dorosłych, zachowań prospołecznych (niesienie pomocy innym poprzez rozwiązywanie zagadek, przekazywanie złoczyńców stróżom prawa) czy szacunek do dorosłych (brak karykturalizacji obserwowanej w pozostałych audycjach).

Ostatnia audycja poddana analizie to „Plan totalnej porażki”, produkcji kanadyjskiej firm Teletoon, Fresh TV Inc. oraz Neptoon Studios, przeznaczona dla grupy 13-15 lat. Na wstępie trzeba zaznaczyć, że omawiana audycja wywołała najwięcej kontrowersji w zespole badawczym, który jednoznacznie i jednomyślnie stwierdził, iż nie powinna ona być oglądana przez dzieci ze względu na język, lansowane postawy i zachowania, wreszcie konstruowany świat zależności między 
mężczyznami i kobietami oraz ludźmi o przeciwstawnych cechach - atrybutach społecznie postrzeganych (gruby-chudy, brzydki-ładny, głupi-mądry, etc.). Ponadto audycja ma na tyle pretensjonalny charakter w swojej wymowie, języku oraz formie, że nie ma w sobie potencjału stania się audycją popularną, kultową wśród dorosłych, jak ma to miejsce w przypadku choćby „Pingwinów z Madagaskaru”. „Plan totalnej porażki” to animowane reality show, w którym grupa bohaterów „zarządzana” (podburzana, podjudzana, wystawiana na próbę) przez prowadzącego walczy, w sposób nieustępliwy, o zwycięstwo i główną nagrodę - pieniądze. Promowane w audycji wartości to: popularność (rozpoznawalność - główne kryterium sukcesu), spryt, pieniądze, sława, obecność w mediach, rywalizacja, sukces (kosztem innych), złośliwość, agresja, przemoc słowna. Bohaterowie to grupa postaci stylizowanych na dorosłych, mających sprawiać wrażenie odzwierciedlenia rzeczywistego świata dorosłych pełnego uprzedzeń, uproszczeń, krzywdy i sukcesów osiąganych kosztem innych. Uczestnicy reality show, rywalizujący o zwycięstwo, są zaprezentowani w sposób karykaturalny, wchodzą ze sobą w chaotyczne, pełne konfliktów relacje. Audycja jest wprost antyspołeczna, próbująca pokazać świat dorosłych w sposób nie tyle przerysowany, ale pełny nieuzasadnionych uproszczeń i zdominowany przez wymienione wyżej, negatywne wartości - przez co z gruntu fałszywy. Program został pod wieloma względami oceniony jako najgorsza z badanych audycji, o chaotycznej, krzykliwej narracji, bez walorów edukacyjnych i z bardzo ograniczonymi walorami estetycznymi obrazujący tzw. formułę slapstick. Głównym celem audycji jest pokazanie grupy bohaterów, rywalizujących ze sobą w rysunkowej parodii reality-show o złożonej narracji. Bohaterowie cechują się wysokim poziomem rywalizacji w grupie, a serial prezentuje niekorzystny obraz dorosłych jako osób chaotycznych, dla których głównymi wartościami są sława, popularność i pieniądze. Audycja jednocześnie promuje antywartości i wyśmiewa pozytywne postawy pomocy, współczucia, zaangażowania. Zwracają uwagę także: funkcjonalizacja współbohaterów (wykorzystywanie drugiej osoby celem osiągnięcia sukcesu - zwycięstwa), liczne wulgaryzmy i kolokwializmy. Relacje damsko-męskie prezentowane są tu w sposób wyuzdany (jak na kreskówkę) i bezpruderyjny (vide: ubiór kobiet-bohaterek). Nie ulega wątpliwości, że ta kreskówka stanowi największe zagrożenie dla dzieci ze wszystkich badanych bajek.

Podsumowując, w przypadku wykresu radarowego 6, poświęconego audycjom emitowanym na kanale Cartoon Network, dość wyraźnie wydać wychylenie krzywych w stronę negatywnych atrybutów kreskówek, w przeciwieństwie np. do ogólnego wykresu krzywych dla analizowanych bajek z kanału MiniMini+. Zwraca również uwagę ogromna niespójność w ocenie audycji Cartoon Netowrk 
w poszczególnych kategoriach. Warto odnotować, że właśnie wśród omawianych kreskówek znalazła się ta, która osiągnęła najwyższy wskaźnik agresji i przemocy - kreskówka „Ben10 Omniverse”. Ponadto właśnie na kanale Cartoon Network można znaleźć najbardziej antyspołeczną - promującą anty-wartości - audycję, czyli „Plan totalnej porażki”.

\section{PANORAMICZNE PODSUMOWANIE BADANIA}

Puentując przedstawione wyniki omawianego badania świata przedstawianego w bajkach warto odnotować, że zachowania ekologiczne (rozumiane jak opisano wyżej) są w tych audycjach prawie nieobecne, co może zaskakiwać. Trudno przesądzić, dlaczego tak się dzieje. Możliwe, że ekologia jest na tyle złożonym problem, iż trudniej go wprowadzić i wytłumaczyć w sposób nietendencyjny aniżeli inne wątki. Może też twórcy tych audycji, działający głównie w Stanach Zjednoczonych oraz Kanadzie, nie dostrzegają istoty tej problematyki. Trudno to stwierdzić jednoznacznie.

Warto nadmienić, że system edukacji, wielokrotnie obrazowany w rzeczonych audycjach, otrzymał relatywnie dobre oceny w tym sensie, że nie zidentyfikowano jawnego negowania istoty systemu edukacji, szkoły czy też zasadności uczęszczania do niej. Ewentualnym problemem, który ma jednak wymiar szerszy, jest karykaturalne, przerysowane przedstawianie dorosłych i ich spraw - ich świata. Ponadto w rzadkich wypadkach dorośli stanowią jednoznacznie pozytywne wsparcie dla bohaterów określonych narracji. Zazwyczaj są przedstawiani jako ci, którzy piętrzą problemy, narzucają ograniczenia i prezentują niską zdolność negocjacyjną w budowaniu ewentualnego porozumienia, konsensu. To tworzy silny podział w postrzeganiu świata dorosłych oraz świata nastolatków, w mniejszym stopniu dzieci poniżej 10. roku życia.

Spoglądając panoramicznie na przygotowane wykresy, można łatwo odnaleźć najlepszy i najgorszy kanał z bajkami dla dzieci. W tej dychotomii po jednej stronie widzimy MiniMini+, po drugiej bezapelacyjnie Cartoon Network. Jeśli zejdziemy na poziom konkretnych audycji, to za najlepsze można uznać bajki emitowane właśnie w MiniMini+, „Pingwiny z Madagaskaru” z Nickelodeon, „Jej Wysokość Zosię” i „Podróże Justina” z Disney Channel. Za najgorsze zaś, bez wątpienia, „Plan totalnej porażki” z Cartoon Network oraz „Spongebob” z Nickelodeon. 


\section{EWALUACJA PROJEKTU BADAWCZEGO I DALSZE KROKI}

Badanie dostarczyło kilku, jak się wydaje, istotnych i inspirujących wniosków. Z pewnością wskazało konieczność podejmowania tego typu analiz o jeszcze szerszym zakresie przedmiotowym i najlepiej cyklicznych, tak by możliwe stało się śledzenie trendów w sposobach konstruowania audycji dla dzieci i nastolatków oraz poszukiwanie związków z kultywowanymi przez tę grupę wzorcami społecznymi i kulturowymi. Trzeba też wskazać kilka wniosków metodologicznych, które z pewnością pomogłyby w precyzyjnym zaprojektowaniu kolejnego badania w tym obszarze.

W pierwszej kolejności należy zaznaczyć, że lepsze rezultaty przyniosłoby rozdzielenie audycji animowanych i audycji aktorskich - z oczywistego względu istotnie rozbieżnych wiekowo grup odbiorców, ale także z powodu nieprzystającej formy produkcji, montażu etc.

Po drugie, należałoby rozważyć poszerzenie kategorii analitycznych, np. o sferę akcentów czy wzorców seksualnych, które nie były poddane badaniu, a w niektórych audycjach odgrywały istotną rolę (na co wskazywał w swojej opinii psycholog rozwojowy, współpracujący z autorami niniejszego tekstu). Podobnie istotna wydaje się kategoria ról płciowych, jakie przyjmują bohaterowie bajek - czy realizują schematyczne założenia o zainteresowaniach chłopców i dziewczynek, czy też je łamią, i jeśli tak, to w jaki sposób. Ten element mógłby okazać się dodatkowo przydatny w analizie odbiorców audycji - jak bowiem sygnalizują nadawcy (autorzy przeprowadzili rozmowy z wybranymi nadawcami niniejszych kanałów dziecięcych), w ostatnich latach można zaobserwować zjawisko oglądania audycji przez grupy płciowe, dla których z założenia te audycje nie są przeznaczone (szczególnie: chłopcy oglądają audycje przeznaczone dla dziewcząt).

Ten wątek prowadzi do trzeciego ważnego wyzwania metodologicznego: określenia profilu rzeczywistego odbiorcy analizowanych audycji. I nie chodzi tu tylko o wspomniane grupy płciowe, ale przede wszystkim grupy wiekowe widzów, którzy oglądają audycje dla siebie nieprzeznaczone. Jak wspomniano wyżej, nadawcy i analitycy rynku mediów sygnalizują także zjawisko drabiny wiekowej, a więc obniżania się wieku rzeczywistych odbiorców audycji dla dzieci i młodzieży wobec adresatów zakładanych. Oznacza to, że dzieci młodsze oglądają bajki przeznaczone dla dzieci starszych, a dzieci starsze - audycje tworzone dla młodzieży. Świadomość tego trendu tworzy kolejne wyzwanie metodologiczne jakkolwiek bowiem wydaje się, że dla uzyskania bardziej precyzyjnych ustaleń należałoby podzielić badane audycje nie tylko ze względu na gatunek, ale i typ 
adresata, tak w praktyce adresat nie jest tożsamy z odbiorcą, przez co wyznaczenie jasnych kryteriów podziału staje się znacznie utrudnione.

Krytyków telewizji jako takiej wśród naukowców nie brakuje. Silny jest też głos badaczy podkreślających zgubny wpływ audycji telewizyjnych na rozwój małych dzieci i dzieci. Kategoryczną diagnozę w tej sprawie stawia w swojej głośnej książce neurobiolog Michel Desmurget, twierdząc: „Telewizja jest złodziejką czasu. Jest również przyczyną społecznej izolacji, źródłem lenistwa intelektualnego, czynnikiem poznawczej jałowości i wektorem rozpadu psychiki. W czasach, gdy rodzice wydają ogromne sumy na korepetycje, by ich pociechom udało się skończyć szkołę, bezkarność Pani Telewizji może wprawiać w zdumienie. Osobliwa schizofrenia, kiedy to z jednej strony oczekuje się doskonałego wykształcenia, z drugiej zaś wystawia nasze dzieci na najbardziej ogłupiające treści medialne” (2012, s. 123-124). Wydaje się, że zwłaszcza w tym kontekście uważna analiza zawartości audycji przeznaczonych dla małoletnich oraz konfrontowanie efektów produkcji bajek z założeniami i deklaracjami nadawców stają się coraz ważniejszymi zadaniami dla medioznawców. Warto też zwrócić uwagę na fakt, że tego typu analizy powinny poprzedzać coraz lepiej rozwijającą się w Polsce edukację medialną - trudno bowiem uczulać zwłaszcza najmłodszych widzów na określone zagrożenia, jeśli nie mamy tych zagrożeń precyzyjnie zidentyfikowanych.

\section{Literatura:}

Center for Youth and Media Studies, The Alliance for Children and Television, (2007). A National Study on Children's Television Programming in Canada. 2010. Pobrane z: http://www.ymamj.org/pdf/nationalstudy.pdf.

Adamczyk, W. (2007). Dokąd wiedzie ekranowy bohater polską młodzież. W: S. Juszczyk, I. Polewczyk (red.), Dziecko w świecie wiedzy, informacji i komunikacji. Toruń: Wydawnictwo Adam Marszałek.

Baker, K., Raney, A.A. (2007). Equally Super - Gender-Role Stereotyping of Superheroes in Children's Animated Programmes. Mass Communication \& Society, 10 (1), s. 25-41.

Bal, M. (2012). Narratologia. Wprowadzenie do teorii narracji. Kraków: Wydawnictwo Uniwersytetu Jagiellońskiego.

Brooks, K. (2003). Nothing sells like teen spirit: the commodification of youth culture.

W: K. Mallan, S. Pearce (red.), Youth cultures, texts, images, and identities. London: Praeger.

Campbell, J. (2013a). Bohater o tysiącu twarzy. Kraków: Nomos.

Campbell, J. (2013b). Potęga mitu. Kraków: Znak.

Common Sense Media Research (2012). Children, Teens, and Entertainment Media: The

View From The Classroom. Pobrane z: http://www.commonsensemedia.org/sites/ default/files/research/view-from-the-classroom-final-report.pdf. 
Cook, J., Main, W. (2008). What is a Princess - Developing an Animated TV Program for Small Girls. Australian Feminist Studies, 23 (57), s. 401-415.

Coyne, S., Whitehead, E. (2008). Indirect Aggression in Animated Disney Films. Journal of Communication, 58, s. 382-395.

D’Allesio, M. i in. (2012). Children's Preference for Television Programs, Journal of Applied Social Psychology, 42 (4), s. 822-833.

Desmurget, M. (2012). Teleogłupianie. O zgubnych skutkach oglądania telewizji (nie tylko przez dzieci). Warszawa: Czarna Owca.

Juszczyk, S., Polewczyk, I. (red.), (2007). Dziecko w świecie wiedzy, komunikacji i informacji. Toruń: Wydawnictwo Adam Marszałek.

Livingstone, S., Haddon, L. (2009). EU Kids Online: Final report. London: EU Kids online. Pobrane z: http://www.lse.ac.uk/media@lse/research/EUKidsOnline/EU\%20 Kids\%20I\%20(2006-9)/EU\%20Kids\%20Online\%20I\%20Reports/pl_summary.pdf.

Feldman, R., Coast, E., Spielman, D. (1996). Television Exposure and Children's Decoding of Nonverbal Behavior. Journal of Applied Social Psychology, 26 (19), s. 1718. Pobrane z: http://www.lse.ac.uk/media@lse/research/EUKidsOnline/EU\%20Kids\%20I\%20 (2006-9)/EU\%20Kids\%20Online\%20I\%20Reports/pl_summary.pdf1733.

Gackowski, T., Łączyński, M., Departament Strategii KRRiT (2012). Polski rynek kanałów zdelokalizowanych - analiza zjawiska i rekomendacje, Analiza Biura KRRiT nr 13/2012. Pobrane z: http://pl.scribd.com/doc/127938909/Analiza-zwi\%C4\%85zanaz-programami-polskoj\%C4\%99zycznymi-rozpowszechnianymi-z-terytorium-innychpa\%C5\%84stw-a-skierowanymi-na-rynek-polski-Temat-analizy-to-Polski.

Gajda, J., Juszczyk, S., Siemieniecki, B., Wenta, K. (2002). Edukacja medialna. Toruń: Wydawnictwo Adam Marszałek.

Gajda, J. (2003). Media w edukacji. Kraków: Oficyna Wydawnicza „Impuls”.

Gajda, J. (1998). Środki masowego przekazu w wychowaniu. Lublin: Wydawnictwo UMCS.

Kaiser Family Foundation (2010). Generation M2: Media in the Lives of 8 - to 18-Year-Olds. Pozyskano z: http://kff.org/other/event/generation-m2-media-in-the-lives-of/.

Gunter, B., Harrison, J. (1997). Violence in Children’s Programmes on British Television. Children \& Society, 11, s. 143-156.

Izdebska, J. (1995). Rodzina, dziecko, telewizja. Szanse wychowawcze i zagrożenia telewizji. Białystok: Trans Humana.

Izdebska, J. (2007). Dzieciństwo medialne współczesnych dzieci. W: J. Izdebska (red.), Dziecko w świecie wiedzy, informacji i komunikacji. Toruń: Wydawnictwo Adam Marszałek.

Izdebska, J. (2007). Dziecko w świecie mediów elektronicznych. Teoria, badania, edukacja medialna. Białystok: Trans Humana.

Kirwil, L. (1999). Elementy interesujące i nudne w programach telewizyjnych dla dzieci. W: J. Chruścińska, E. Kubisz (red.), Dzieci a mass media. Materiały z ogólnopolskiego seminarium, Zielona Góra, 22-23 października 1998 roku, Warszawa: Centrum Ustawicznego Kształcenia Dziennikarzy.

Kołodziejczyk, A. (2003). Dziecięca koncepcja fikcji, czyli co jest „na niby” w telewizji. Kraków: Wydawnictwo Uniwersytetu Jagiellońskiego. 
Korr, J. (2008). Healthy Cartoons - a content analysis of food in children's animated television programs. Food, Culture and Society, 11 (4), 449-462.

Kossowski, P. (1999). Dziecko i reklama telewizyjna. Warszawa: Żak.

Krajewska, A. (2003). Obraz świata społecznego w filmach animowanych dla dzieci. W: B. Łaciak (red.), Dziecko we współczesnej kulturze medialnej. Warszawa: Instytut Spraw Publicznych.

Lévi-Strauss, C. (2009). Antropologia strukturalna. Warszawa: Aletheia.

Łaciak, B. (2003). Obraz dziecka w prasie i telewizji. W: B. Łaciak (red.), Dziecko we współczesnej kulturze medialnej. Warszawa: Instytut Spraw Publicznych.

Litwińska, K. (2008). Reklamy telewizyjne i ich oddziaływanie na emocje dzieci w wieku przedszkolnym. Lublin: Wydawnictwo Katolickiego Uniwersytetu Lubelskiego.

López-Sánchez, C., Tur-Viñes, V., García-Castillo, J. (2010). Evaluation of the protagonist-antagonist dichotomy in Spanish television content targeting children. Revista Latina de Comunicación Social, 65, s. 553-560.

TNS OBOP (2004). Lubimy rozmawiać z dziećmi. Pobrane z: http://obop-arch.tnsglobal. pl/uploads/753/TNSOBOP_rodzice_dzieci.doc.

Siemieniecki, B. (red.), (2006a). Manipulacja informacją w mediach a edukacja. Toruń: Wydawnictwo Adam Marszałek.

Siemieniecki, B. (red.), (2006b). Manipulacja, media, edukacja. Toruń: Wydawnictwo Adam Marszałek.

Marcol, K. (2006). Wpływ mediów na folklor dziecięcy. W: S. Juszczyk, I. Polewczyk (red.), Media wobec wielorakich potrzeb dziecka. Toruń: Wydawnictwo Adam Marszałek.

Strykowski, W. (red.), (2000). Media a edukacja. Poznań: eMPi2.

Izdebska, J. (red.), (2009). Media elektroniczne - kreujące obraz rodziny i dziecka. Białystok: Trans Humana.

Lewowicki, T., Siemieniecki, B. (red.), (2008). Media w edukacji - szanse i zagrożenia. Toruń: Wydawnictwo Adam Marszałek.

Juszczyk, S., Polewczyk, I. (red.), (2005). Media wobec wielorakich potrzeb dziecka. Toruń: Wydawnictwo Adam Marszałek.

Musioł, M. (2006). Media w procesie wychowania. Toruń: Wydawnictwo Adam Marszałek. Noxon, C. (2006). Rejuvenile: Kickball, Cartoons, Cupcakes, and the Reinvention of the American Grown-up. New York: Penguin Random House.

Departament Polityki Europejskiej i Współpracy z Zagranicą, Departament Programowy Biura KRRiT (2011). Ochrona małoletnich w radiu i telewizji - kontekst międzynarodowy i doświadczenia polskie. 2011. Pobrane z: http://www.krrit.gov.pl/dla-abonentow-i-konsumentow/komunikaty-prasowe/news,394,czy-stosowane-przez-nadawcow-ozn aczenia-programow-chroniacych-dzieci-i-mlodziez-sa-skuteczne.html.

Padilla-Walker, L., Coyne, S., Fraser, A., Stockdale, L. (2013). Is Disney the Nicest Place on Earth - A Content Analysis of Prosocial Behavior in Animated Disney Films, Journal of Communication, 63, s. 393-412.

Propp, W. (2011). Morfologia bajki magicznej. Kraków: Nomos.

Łachowska, E. (2013). Raport z diagnozy ryzyka uzależnienia od komputera, Internetu 
i innych mediów cyfrowych. Zespół Szkół Publicznych w Czerniejewie. Pobrane z: http://czerniejewo.org/pdf/diagnoza_komputer.pdf [dostęp: 21.03.2015].

Departament Programowy KRRiT (2010). Raport z monitoringu programów adresowanych do dzieci i młodzieży: ZigZap i MiniMini (na próbie programu nadanego w okresie 18-24 marca 2009 roku). Pobrane z: http://www.krrit.gov.pl/Data/Files/_public/Portals/0/kontrola/program/100629_monitoring_zigzap_minimini.pdf.

Robinson, T., Anderson, C. (2006). Older Characters in Children's Animated Television Programs. A Content Analysis of Their Portrayal. Journal of Broadcasting \& Electronic Media, 50 (2), s. 287-304.

Rozporządzenie KRRiT z dnia 23 czerwca 2005 roku w sprawie kwalifikowania audycji lub innych przekazów mogących mieć negatywny wpływ na prawidłowy fizyczny, psychiczny lub moralny rozwój małoletnich oraz audycji lub innych przekazów przeznaczonych dla danej kategorii wiekowej małoletnich, stosowania wzorów symboli graficznych i formuł zapowiedzi, Dz.U. 2005 nr 130 poz. 1089. Pobrane z: http://isap. sejm.gov.pl/DetailsServlet?id=WDU20051301089.

Ryan, E. (2010). Dora the Explorer - Empowering Preschoolers, Girls, and Latinas, Journal of Broadcasting \& Electronic Media, 54 (1), s. 54-68.

Siemieniecki, B. (2007). Pedagogika medialna. Warszawa: PWN.

Sitarczyk, M. (2005). Bohater telewizyjny w percepcji dzieci 6-letnich. W: L. Dyczewski (red.), Rodzina, dziecko, media. Lublin: Gaudium.

Sosnowski, T. (2006). Telewizja w życiu dzieci hospitalizowanych. W: S. Juszczyk, I. Polewczyk (red.), Media wobec wielorakich potrzeb dziecka. Toruń: Wydawnictwo Adam Marszałek.

Klus-Stańska, D. (red.), (2004). Światy dziecięcych znaczeń. Warszawa: Wydawnictwo Akademickie Żak.

TNS OBOP, Gazeta Prawna (2009). Telewizor pilnuje dzieci. Pobrane z: http://tv-cyfrowa. eu/content/tns-obop-telewizor-pilnuje-dzieci.

Office of Communications (2007). The future of children's television programming. Pobrane z: http://stakeholders.ofcom.org.uk/binaries/consultations/kidstv/summary/ kidstv.pdf.

Ustawa z dn. 29 grudnia 1992 r. o radiofonii i telewizji, Dz.U. 1993 nr 7 poz. 34. Pobrane z: http://isap.sejm.gov.pl/DetailsServlet?id=WDU19930070034.

Wenta, K. (2007). Teletubisie w oddziaływaniach na zachowania małego dziecka. W: S. Juszczyk, I. Polewczyk (red.), Dziecko w świecie wiedzy, informacji i komunikacji. Toruń: Wydawnictwo Adam Marszałek.

Parents Television Council (2006). Wolves in Sheep's Clothing. A Content Analysis of Children's Television. Pobrane z: https://www.parentstv.org/PTC/publications/reports/ childrensstudy/childrensstudy.pdf. 